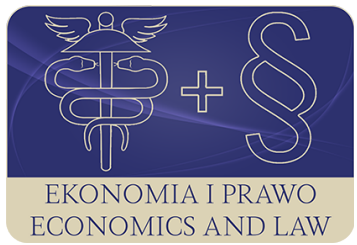

EKONOMIA I PRAWO. ECONOMICS AND LAW

Volume 15, Issue 3, September 2016

p-ISSN 1898-2255, e-ISSN 2392-1625

www.economicsandlaw.pl

ORIGINAL ARTICLE

received 04.03.2016; revised 13.08.2016; accepted 30.09.2016

Citation: Bochenek, M. (2016). Paul Anthony Samuelson and his work (on the hundredth anniversary of his birth). Ekonomia i Prawo. Ecomomics and Law, 15(3): 265-278.

doi:10.12775/EiP.2016.017.

\title{
Paul Anthony Samuelson and his work (on the hundredth anniversary of his birth)
}

\author{
MIROSEAW BOCHENEK \\ Nicolaus Copernicus University, Faculty of Economic Sciences and Management, Department \\ of Economics, ul. Gagarina 13A, 87-100 Toruń, Poland \\ $\square$ bochenek@econ.umk.pl
}

\begin{abstract}
Aim: The purpose of this article is an attempt to systematise and evaluate the achievements of the American Nobel laureate in economic sciences and co-founder of "neoclassical synthesis' - P.A. Samuelson.

Motivation: This economist greatly developed the methodology and theory of economics. Preferring the mathematical method in scientific inquiry and introducing new graphic solutions, he contributed to the mathematisation of economics. He enriched the theory of consumption by revealed preferences, devised the $45^{\circ}$ line to determine the Keynesian short-term equilibrium in the goods market, as well as the consumer demand, investment demand, and savings function curves, and he also defined collective goods. He completed the theory of division with the modified Lorenz curve, presented the problem of the allocation of scarce resources by the curve of production possibilities, and generalised - together with R.M. Solow - the Phillips curve. In addition, he created a model of the interdependence of the multiplier and accelerator, and developed the theory of foreign trade by the 'Stolper-Samuelson effect' and the statement of the impact of prices of production factors on the allocation of resources.

Results: Caring for affordability of the exposition of basic economic knowledge contained in his textbook Economics, he made a revolution in the teaching of economics. Owing to these achievements, P.A. Samuelson earned his inclusion in the circle of the greatest economists of the twentieth century.
\end{abstract}


Keywords: history of economic thought; neoclassical synthesis; Keynesian theory; division theory; business cycle theory; the theory of international trade; the theory of inflation and unemployment JEL: B2; B21; B22; D3; E12; E13; E31; E32; F10; J64

\section{Introduction}

In 2015 occurred the centenary of the birth of the prominent American economist, P.A. Samuelson. He is widely known as the author of the world's most popular economics textbook $\mathrm{k}^{1}$ and as a winner of the Nobel Prize in economic sciences. The scientist created a series of original and still valid concepts and made a revolution in the teaching of economics. That round number anniversary is therefore a good opportunity to tell a few words about his life history and to systematise his achievements in the field of the science cultivated by him. Unfortunately, owing to the limited scope of this study, the author was forced to make a selection and present only the most important works and thoughts of the rich heritage of the scholar who is the subject of this article.. The method of historical analysis has been applied here.

\section{P.A. Samuelson's Biography ${ }^{2}$}

P.A. Samuelson was born on 15 May 1915 in Gary, Indiana, into the Jewish family of Frank Samuelson (pharmacist) and Ella nee Lipton, who came to the USA before the First World War. In 1932, he began his studies in economics at the University of Chicago, which he continued at Harvard University and completed in 1941 with a PhD degree. A year earlier he had joined the Massachusetts Institute of Technology; he was first employed as an assistant professor, and in 1947 he was appointed professor of economics. In the MIT he created the department of doctoral economic studies which enjoyed a high reputation. For many years he worked as an economic columnist for 'Newsweek' magazine. In the years 1961-1963 he served as economic adviser to President John F. Kennedy. He was also a scientific consultant to the National Resources Planning Board, the War Production Board, the Office of War Mobilization and Reconstruction, the United States Treasury, the Bureau of the Budget, the National Goals Commission, the Board Committee for Economic Development, the Rand Corporation, the Federal Reserve Bank, and a member of the National Task

${ }^{1}$ Since 1985, i.e. from the 12th edition, W.D. Nordhaus has been co-author of the textbook. This work was first published in Polish in 1965 in fragments. See Samuelson (1965, pp. 163-428). The whole work of the American Nobel Prize winner was released in our country only in 1995-1996. See Samuelson \& Nordhaus (1995, 1996). In 2004, the PWN resumed the publication of the above work (2nd ed., Vol. 1-2), whereas in 2012, the third, uniform edition was published, which was a new translation of the 19th edition of the original, made by other translators and published by another publishing house. See Samuelson \& Nordhaus (2012).

2 Based on Semkow (1988, pp. 287 et al.) and Nobelprize.org (2016). 
Force on Economic Education. He belonged to many scientific societies, that is: the American Philosophical Society, the American Academy of Arts and Sciences, the National Academy of Sciences, Phi Beta Kappa, and the British Academy, and he served as president in the Econometric Society, the American Economic Association, and the International Economic Association. The University of Chicago, Indiana University, East Anglia University, Oberlin College, Ripon College, Boston College, the University of Michigan, and Claremont Graduate School conferred honorary doctorates on him. In 1970, he won the Nobel Prize in economic sciences 'for scientific work on the basis of which he developed the static and dynamic economic theory and actively contributed to the improvement of the level of analysis in economic sciences'. He died on 13 December 2009 in Belmont, Massachusetts.

The matters considered by the American economist included most of the issues of economics. In his numerous publications, among others: The Operational Significance of Economic Theory (1941), Foundations of Economic Analysis (1947), Economics. An Introductory Analysis (1948), Readings in Economics (1952), Linear Programming and Economic Analysis (co-authors: R. Dorfman, R.M. Solow, 1958), International Economic Relations (1959), Problems of the American Economy (1962), Stability and Growth in the American Economy (1963) as well as The Collected Scientific Papers of P.A. Samuelson (7 vol., 1966-2011), integrated and systematised the whole theory of economics and, as a result, contributed to the creation of a new economic school, called the 'neoclassical synthesis', and through the use of the language of mathematics, he contributed to the mathematisation of economics ${ }^{3}$. He made a huge contribution to the development of the theory of consumption (he introduced the concept of 'revealed preferences' (Samuelson, 1947, pp. 90-123; 1959, pp. 92-117)), the theory of capital (Dorfman et al., 1971, pp. 213 et seq.), the theory of collective goods (Samuelson, 1954, pp. 387-389), the theory of foreign trade and economic growth, the theory of inflation and unemployment, and the methodology of economics.

\section{The neoclassical synthesis}

The neoclassical synthesis created by the P.A. Samuelson, J.R. Hicks, F. Modigliani, D. Holme Robertson, J.W. Fellner, and R.M. Solow boiled down to a combination into an integral whole of A. Marshall's neoclassical microeconomics with J.M. Keynes's macroeconomics. The creation of this synthesis did not consist in a mechanical combination of conflicting theoretical systems, but in the coordination and generalisation of certain theories and views that would give the opportunity to explain the mechanism of the functioning of the entire economy. The neoclassical synthesis was, therefore, not only a combination of microand macroeconomics, but also statics and dynamics, general and partial equilibrium, and economic theory and policy. The creation of the neoclassical synthesis

${ }^{3}$ Most of his works are mathematicised works. See among others: Samuelson (1947, pp. 10 et seq.; 1979, pp. 167-183) and Dorfman et al. (1987, pp. 8 et seq.). 
was - according to P.A. Samuelson - a response to the needs of the contemporary economy which has become a mixed economy. In this economy, private initiative is subject to government modifications, and the mechanism of competition is distorted by monopolies. The monopolies which have come into being in the market weaken competition, cause an increase in prices, and condemn some resources to inaction. In a spontaneous market, income is not distributed fairly. In this situation, the state is forced to intervene in the economy. Achieving equilibrium at full employment requires an artificial increase of investment, even unprofitable investment. Such possibilities rest with the state, which can increase employment during a crisis of overproduction, making additional investments. The state should focus on crisis prevention and not on anti-depression activities. In a mixed economy, the overriding objective of economic policy is to ensure full employment and to match capitalist individualism with social needs (Samuelson, 1961, pp. 37 et seq.; Samuelson \& Nordhaus, 1995, pp. 79 et seq.).

The American economist rejected A. Smith's liberalistic idea of the harmonisation of private interests with the interests of the general public. P.A. Samuelson argued that the thesis of the 'father of economics', justifying free enterprise was based on the assumption of perfect competition. In modern economies, the most important markets have been dominated by a small number of companies. It is imperfect competition that should be considered a normal condition. He pointed to the helplessness of the market in the solving of problems which are accompanied by external effects, or the effects of the activities of private companies in the form of both costs (pollution) and benefits (more beautiful surroundings) (Samuelson, 1961, pp. 177 et seq.; Samuelson \& Nordhaus, 1995, pp. 86 et seq.).

\section{The methodology and didactics of economics}

P.A. Samuelson outlined his own research programme in Zasady analizy ekonomicznej. He included in it not only the previously mentioned criteria, propositions, rules, and terms which were a landmark in the methodology of economics, but also analysed the majority of issues falling within the scope of economics. He considered the stability of an economic system in the context of the interdependence of economic statics and dynamics. The static models contain the necessary conditions for the equilibrium of dynamic models. Statics acts as a starting point for dynamic considerations. Static models are timeless models, whereas in dynamic models time is treated as a fundamental variable. The properties of static systems also determine the durability of dynamical systems. Dynamical systems satisfy the durability condition if they automatically strive for equilibrium or oscillate around equilibrium (Samuelson, 1959, pp. 60 et seq.; 1947, pp. 57 et seq.). P.A. Samuelson believed that the economy still faces many important unresolved issues that require further investigation, such as issues of comparative statics and dynamics. In the conclusion of Zasady analizy ekonomicznej, the au- 
thor wrote: 'Further development of analytical economics in terms of comparative dynamics is a matter of the future. We can hope that it will help in solving a number of issues: from the simplest ones to the behaviour of a single commodity, to the fluctuation of the important components of the business cycle, and even to the vast issues of economic development' (Samuelson, 1959, pp.339 et seq.; 1947, p. 355).

Within the framework of the methodology of economics, he dealt with the principle of correspondence, operationalism, descriptivism, a proposition of significance (the significant theorem or the fundamental theorem of economics), criticism of the basic version of the F distortion that is the theorem of invalidity of assumptions, and he made a distinction between the quantitative account and the qualitative account (Samuelson, 1947, pp. 3 et seq.; 1959, pp. 5 et seq.; Stiglitz, 1970, pp. 1751-1778; Merton, 1972, pp. 758-766).

The intention of P.A. Samuelson was also the preparation and presentation of an affordable exposition of basic economic knowledge. To this purpose served his textbook Economics. An Introductory Analysis (1948). In subsequent editions of the handbook the number of graphic images of the relationships between economic phenomena and statistical data was increased. On the basis of these solutions, P.A. Samuelson made a breakthrough, called a revolution, in the teaching of economics and set new standards in the presentation of individual concepts and the teaching of the western economy.

\section{Promoting Keynesianism}

An important accomplishment of P.A. Samuelson was the dissemination of J.M. Keynes's idea as well as a simple presentation of the Keynesian model and his main thought that global spending in all sectors of the economy determines the volume of production. The elements of this solution were introduced in the first edition of Economics. An Introductory Analysis and they comprised the $45^{\circ}$ line and consumer demand, investment demand, and savings functions curves (picture 1) (Samuelson, 1955, pp. 214-228; Samuelson \& Nordhaus, 1995, pp. 201-248).

In Samuelson's view of the Keynesian model, the short-term balance of goods and services in the market is determined by the point of intersection of the curve of the total expenditure $C+I$ with a line drawn at an angle of $45^{\circ}$. Global demand is then a fundamental determinant of manufacturing balancing the market $\left(Y_{0}\right)$.

At the level of production that ensures a balance on the market of goods and services $\left(Y_{0}\right)$, also planned, or otherwise desirable, household savings will equate with the investment desired by the company. This relationship is represented by the point of intersection of the investment demand curve $I$ and the savings function $S$ (picture 2). 


\section{Lorenz curve}

The $45^{\circ}$ line was also used by P.A. Samuelson to modify the diagram which measures the variation among income groups, called the Lorenz curve. On the axis of ordinates he put the cumulative percentage of income, while on the axis of abscissae - the cumulative percentage of the number of households. In the modernised perspective the diagram consists of three curves. The $45^{\circ}$ line corresponds to the line of perfectly equal distribution between households, otherwise known as the line of absolute equality, imaging egalitarian distribution. It denotes a layout in which the distribution of income is equal, which means that $20 \%$ of households reach $20 \%$ of income, etc. The curve of perfectly unequal distribution of income refers to a case where $99 \%$ of households do not receive any income, and $1 \%$ of households take over the total income. In reality, the distribution of income is not equal, as shown in the chart by the Lorenz curve, located below the $45^{\circ}$ line. Thus, the curve of actual income distribution reflects a differentiation of income in the economy, or an income inequality. The farther away the Lorenz curve is from the line of absolute equality, the greater is the income inequality of households (Samuelson, 1955, pp. 63-65; 130-132; Samuelson \& Nordhaus, 1996, pp. 12-25).

\section{The problem of allocation of scarce resources}

According to the author of Economics. An Introductory Analysis, every society faces the problem of allocation of scarce resources, labour, land, and capital, a problem which has been known since ancient times. From the available resources various goods and services can be produced. The various societies, regardless of economic organisation, must decide what goods to produce, and thus also determine the appropriate allocation of resources. The choices from among alternative production possibilities available to the public were presented by P.A. Samuelson using a pictorial diagram and the curve of production possibilities, known also as the transformation curve.

All available resources may be used exclusively in the production of butter or in the production of cannons (two extreme cases), or one can use them to produce simultaneously two goods in various proportions. The production possibilities curve represents various combinations of production of two goods, making full use of existing resources in a given economy (Samuelson, 1955, pp. 17-20).

\section{The multiplier-accelerator model}

The article Interactions Between the Multiplier Analysis and the Principle of Acceleration (1939) won its author international acclaim. By introducing the element of time to the Keynesian static description of the conditions of fluctuations in production and employment, P.A. Samuelson developed the dynamic concept of capitalist economy transition from the growth phase to the decline phase etc. 
By analysing the relationship between income, consumption, and investment it showed that a disequilibrated economy does not proceed to the new state of equilibrium. Both in the recovery phase, as well as the decline phase, the intensity of growth or decline decreases, and then reaches a turning point. The economy is thus a periodically dynamic system. In his model, called 'Samuelson's model of interdependence of multiplier and accelerator', he assumed that the national income $Y_{t}$ is the mooring line for consumer spending $C_{t}$, investment spending $I_{t}$, and government spending on goods and services $G_{t}$. Treating $G_{t}$ as an exogenous factor, he assumed that it is a constant and marked it as $G_{0}$. He treated consumption as a function of income from the previous period which is directly proportional to the $Y_{t-1}$. The investments are by definition divided into autonomous and induced, or derivative, or otherwise stimulated. Autonomous investment does not depend on current income. Derivative investments $I_{t}$ react to changes in consumption; they are a function of consumer spending. Through induced investment, the principle of acceleration was introduced into the model. Its operation makes yield vary more than investment. P.A. Samuelson described his model using the following system of equations:

$$
\begin{aligned}
& Y_{t}=C_{t}+I_{t}+G_{0}, \\
& C_{t}=b Y_{t-1}, \\
& I_{t}=\alpha\left(C_{t}-C_{t-1}\right),
\end{aligned}
$$

where $b(0<b<1)$ is the marginal propensity to consumption, while $\alpha$ ( $\alpha>0)$ is the factor of acceleration (accelerator).

Through this model, the author showed that the mere existence of the relationship between the multiplier and the accelerator can generate short-term cyclical fluctuations in production (Samuelson, 1939, pp. 75-78).

\section{Supplementing the theory of foreign trade}

Another area of interest for P.A. Samuelson was the theory of international trade. In his opinion, international economic relations must obey the principle of free trade which leads to the maximisation of global output, thanks to the optimal use of resources on a world scale. Free international trade makes all participants achieve the benefits of the international division of labour, with the result that the world product is maximised. P.A. Samuelson, however, allowed the use of credit and financial policy in the form of tax credit, taxes and subsidies, serving as tools to protect internal markets, instead of the traditional customs policy.

He argued that the theory of comparative costs is flawed because of its staticity and skipped consequences of the imbalance of payments, movements of wages and prices, and the presence of inflationary and deflationary gaps. On the basis of the observation and analysis of international trade, he stated that as a result of international trade the prices of factors of production equalise in the countries involved in exchange. Together with W.F. Stolper, he was also 
preoccupied with price changes in the distribution of income across countries. In the article, Protection and Real Wages (1941), its authors formulated a theorem, called the 'effect' or 'Stolper-Samuelson theorem' which states that changes in relative prices of goods cause more than proportional changes in the prices of factors of production, as well as the income from the factors of production used intensively (Stolper \& Samuelson, 1941, pp. 58-73). This theorem is an original complement to B.G. Ohlin's theory of foreign trade. However, in the studies: International Trade and the Equalisation of Factor Prices (1948), Factor-Price Equalization Once Again (1949) and A Comment on Factor-Price Equalization (1951) P.A. Samuelson claimed that the allocation of resources under conditions of free international exchange is determined by the prices of factors of production. The American Nobel laureate indicated that countries receive benefits from international exchange, and they lose if they do not participate in the exchange. He also formulated the conditions for international exchange, the fulfilment of which would cause a total alignment of the prices of production factors. He included in these conditions perfect competition in the market of goods and factors of production, production factors which are identical in terms of quality, partial specialisation, the same production functions in individual countries, and finally the lack of transport costs (Samuelson, 1948, pp. 163-184; 1949, pp. 181-197; 1951, pp. 1-20).

\section{Phillips curve}

P.A. Samuelson, together with Robert M. Solow, also contributed to the development and popularisation of the Phillips curve. In the study Analytical Aspects of Anti-Inflation Policy (1960) he formulated a theorem on the existence of the functional relationship between the rate of growth of nominal wages and the rate of increase of prices. Assuming that the inflation rate is the difference between the rate of growth of nominal wages and the growth rate of labour productivity, P.A. Samuelson and R.M. Solow replaced - according to Phillips - the percentage change in nominal wage inflation, giving it a more generalised form. In this version, the Phillips curve has become an illustration of the possibilities for the substitution of a certain rate of inflation for a certain unemployment rate. American economists also showed that this curve can be used in the selection of alternative variants of business policy options with various combinations of inflation and unemployment. According to P.A. Samuelson and R.M. Solow (1960, pp. 177-194), it was a long-term replacement relationship between inflation and unemployment that gave politicians the opportunity to choose the preferred variant of business policy. Moreover, in 1964, in the sixth edition of Economics, P.A. Samuelson gave the curve the name 'Phillips curve' (Blaug, 1994, pp. 680, 682). 


\section{Conclusion}

A review of the above achievements clearly indicates that P.A. Samuelson significantly contributed to the development of economics. He joined the circle of the most prominent economists of the twentieth century. The Nobel Prize in economic sciences was the crowning achievement of his research. The scope of his scientific interests included the whole theory of economics. To the greatest possible extent he also contributed to the emergence of the "neoclassical synthesis'. The neoclassical synthesis which, according to P.A. Samuelson, is a combination of micro- and macroeconomics, statics and dynamics, general and partial equilibrium, and the theory of economics and economic policy, was to describe and explain the functioning of a real market economy, which had become a mixed economy.

P.A. Samuelson enriched the theory and methodology of economics by many important findings, drawing inspiration from his excellent knowledge of the history of economic thought and supporting his arguments with it. His most important achievements in the methodology of economics include, among other things, the principle of correspondence, operationalism, descriptivism, the fundamental theorem of economics, and the theorem of invalidity assumptions. In his investigations he preferred to use the language of mathematics, as a result of which he contributed to the mathematisation of economics. He supplemented the economics of the public sector with a precise definition of collective goods. Thanks to his concept of 'revealed preferences' a development of the theory of consumption occurred. He was the first to apply the $45^{\circ}$ line and the curves of consumer demand, investment demand, and savings functions for the presentation of the Keynesian short-term equilibrium in the market of goods and services. He enriched the theory of division by a diagram modified by himself, called the Lorenz curve, which measures the income inequality of households. Using a pictorial diagram and the original curve of production possibilities, he explained the nature and a way of solving the problem of allocating limited resources. A model of interdependence of multiplier and accelerator is P.A. Samuelson's original contribution to the theory of growth and prosperity. He added to the theory of foreign trade the 'Stolper-Samuelson effect' and the assertion that states that under the conditions of free trade the prices of production factors decide the allocation of resources. Complementary to the theory of inflation and unemployment was the generalised - together with Robert M. Solow form of the Phillips curve the name of which is the work of P.A. Samuelson.

In his textbook Economics, P.A. Samuelson introduced - abundantly using geometry tools - a straightforward exposition of basic economic knowledge, and thus set new standards in the presentation of individual concepts and the teaching of western economics, becoming the author of a revolution in the teaching of economics. 


\section{References}

Blaug, M. (1994). Teoria ekonomii. Ujęcie retrospektywne. Warszawa: PWN.

Dorfman, R., Samuelson, P.A., \& Solow, R.M. (1971). Efficient Programmes of Capital Accumulation. In: G.C. Harcourt, \& N.F. Laing (Eds.). Capital and Growth, Selected Readings. Harmondsworth-Baltimore-Ringwood: Penguin Books.

Dorfman, R., Samuelson, P.A., \& Solow, R.M. (1987). Linear Programming and Economic Analysis. New York: Dover Publications.

Merton, R.C. (Ed.). (1972). The Collected Scientific Papers of Paul A. Samuelson. Vol. 3, Cambridge-Massachusetts: The MIT Press.

Nobelprize.org. (2016). Paul A. Samuelson-Biographical. Retrieved 29.02.2016 from http://www.nobelprize.org.

Samuelson, P.A. (1939). Interactions Between the Multiplier Analysis and the Principle of Acceleration. Review of Economics and Statistics, 21(2). doi:10.2307/1927758.

Samuelson, P.A. (1947). Foundations of Economic Analysis. New York: Atheneum.

Samuelson, P.A. (1948). Inernational Trade and the Equalisation of Factor Prices. Economic Journal, 58(230). doi:10.2307/2225933.

Samuelson, P.A. (1949). Inernational Factor-Price Equalization Once Again. Economic Journal, 59(234). doi:10.2307/2226683.

Samuelson, P.A. (1951). A Comment on Factor-Price Equalization. Review of Economic Studies, 19(2). doi:10.2307/2295740.

Samuelson, P.A. (1954). The Pure Theory of Public Expenditure. The Review of Economics and Statistics, 34(4). doi:10.2307/1925895.

Samuelson, P.A. (1955). Economics. An Introductory Analysis, third edition. New York-Toronto-London: McGraw-Hill Book Company.

Samuelson, P.A. (1959). Zasady analizy ekonomicznej. Warszawa: PWN.

Samuelson, P.A. (1961). Economics. An Introductory Analysis, fifth edition. New York-Toronto-London: McGraw-Hill Book Company.

Samuelson, P.A. (1965). Ekonomika. In F. Benham, P.A. Samuelson, G.M. Meier, R.E Baldwin, \& W.J. Baumol. Wyktady ekonomii politycznej. Wybór tekstów. Warszawa: PWN.

Samuelson, P.A. (1979). Land and the Rate of Interest. In H.I. Greenfield, A.M. Levenson, W. Hamovitch, \& E. Rotwein (Eds.). Theory for Economic Efficiency: Essays in Honor of Abba P. Lerner. Cambridge-Massachusetts-London: The MIT Press.

Samuelson, P.A., \& Nordhaus W.D. (1995). Ekonomia, Vol. 1. Warszawa: PWN. Samuelson, P.A., \& Nordhaus W.D. (1996). Ekonomia, Vol. 2, Warszawa: PWN. Samuelson, P.A., \& Nordhaus W.D. (2012). Ekonomia. Poznań: Rebis.

Samuelson, P.A., \& Solow R.M. (1960), Analytical Aspects of Anti-Inflation Policy. The American Economic Review, 50(2).

Semkow, J. (1988). Śladami wielkich ekonomistów. Warszawa: PWN. 
Stiglitz, J.E. (Ed.). (1970). The Collected Scientific Papers of Paul A. Samuelson. Vol. 2, Cambridge-Massachusetts: The MIT Press.

Stolper, W., \& Samuelson P.A. (1941). Protection and Real Wages. Review of Economic Studies, 9(1).

\section{Acknowledgements}

Author contributions: author have given approval to the final version of the article. 


\section{Appendix}

Picture 1.

Short-term equilibrium in the Keynes's model

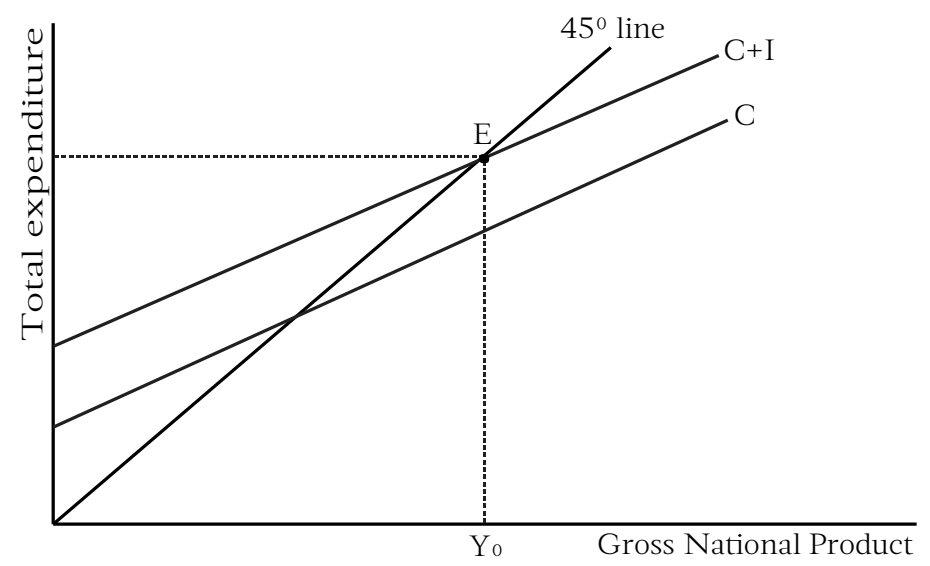

Picture 2.

Planned investment is equal to planned savings

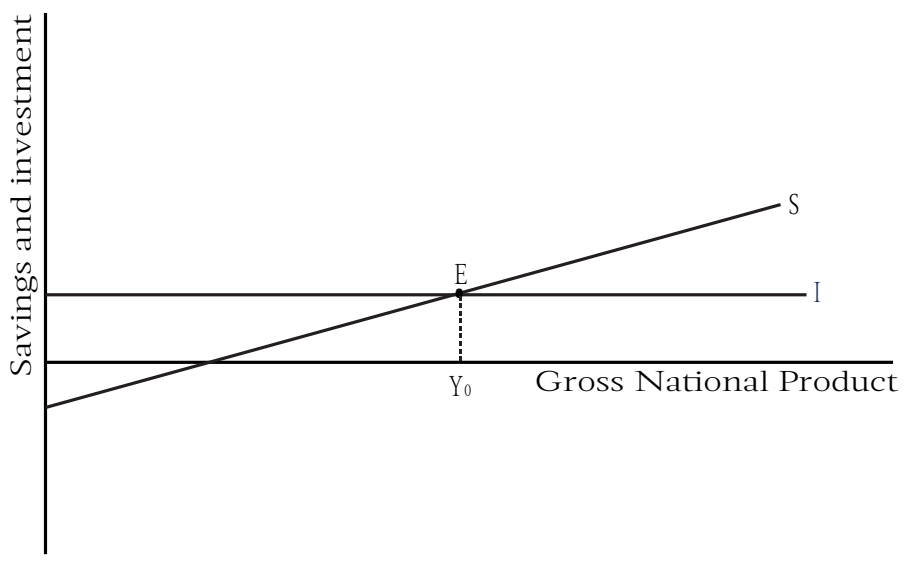


Picture 3.

The Lorenz curve according to P.A. Samuelson

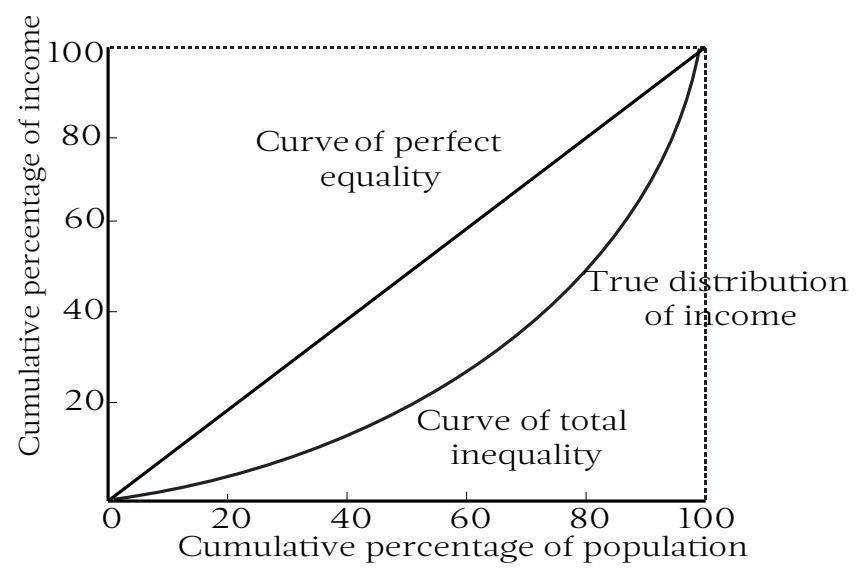

Picture 4.

Curve of production possibilities

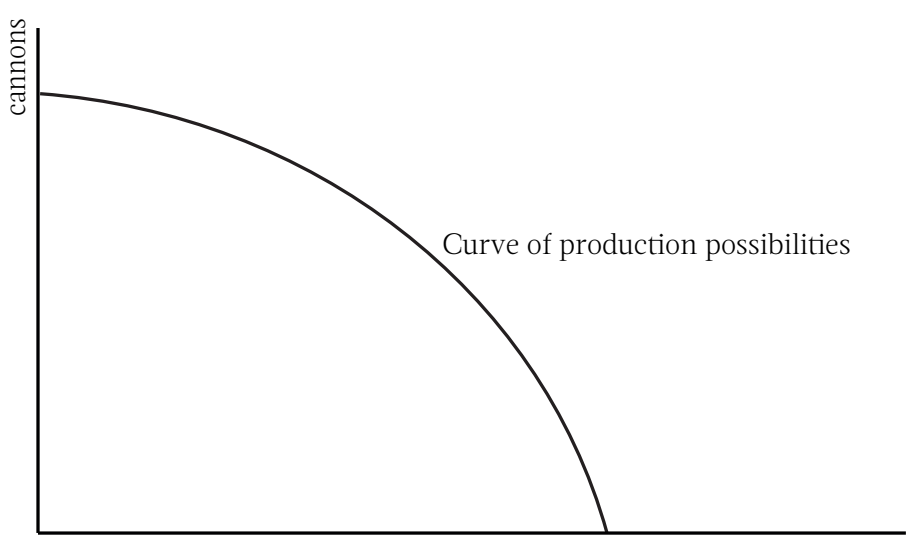

butter 
Picture 5.

The Phillips curve

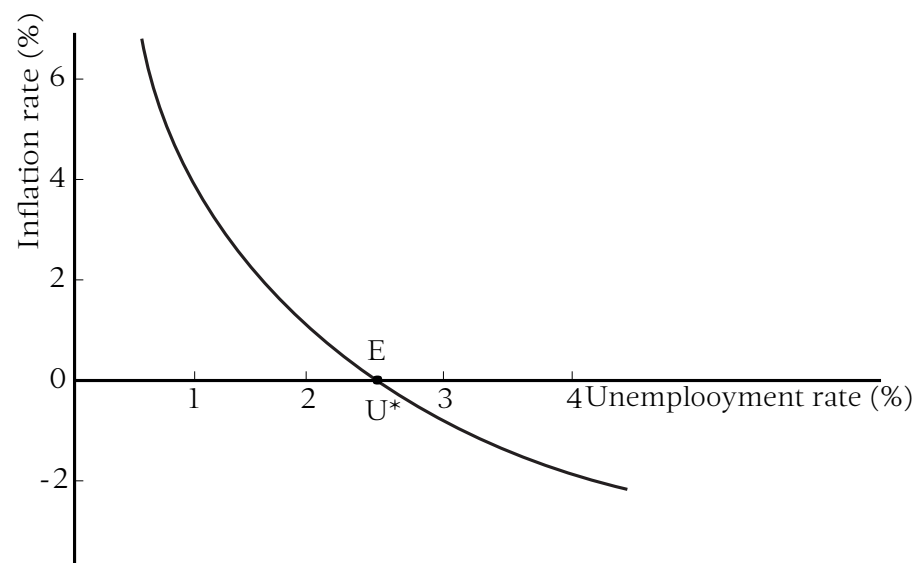

